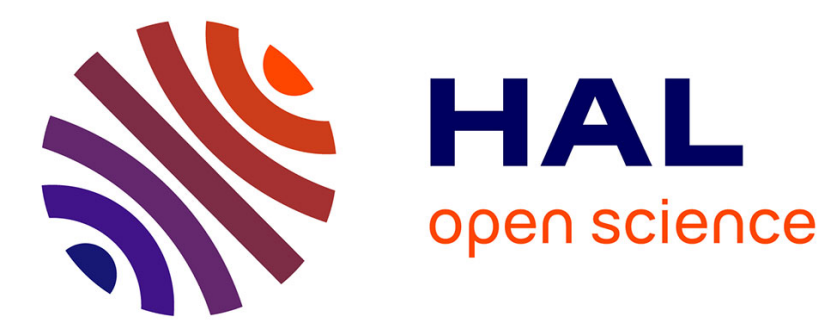

\title{
VUV SPECTROSCOPY OF Ar9 + AND Kr9 + LOW ENERGY COLLISION WITH H2
}

\author{
M. Druetta, T. Bouchama, S. Martin, J. Désesquelles
}

\section{To cite this version:}

M. Druetta, T. Bouchama, S. Martin, J. Désesquelles. VUV SPECTROSCOPY OF Ar9 + AND Kr9 + LOW ENERGY COLLISION WITH H2. Journal de Physique Colloques, 1988, 49 (C1), pp.C1-365-C1-368. 10.1051/jphyscol:1988179 . jpa-00227593

\section{HAL Id: jpa-00227593 https://hal.science/jpa-00227593}

Submitted on 1 Jan 1988

HAL is a multi-disciplinary open access archive for the deposit and dissemination of scientific research documents, whether they are published or not. The documents may come from teaching and research institutions in France or abroad, or from public or private research centers.
L'archive ouverte pluridisciplinaire HAL, est destinée au dépôt et à la diffusion de documents scientifiques de niveau recherche, publiés ou non, émanant des établissements d'enseignement et de recherche français ou étrangers, des laboratoires publics ou privés. 
VUV SPECTROSCOPY OF Ar ${ }^{9}$ AND $\mathrm{K}^{9}+$ LOW ENERGY COLLISION HITH $\mathrm{H}_{2}$

\author{
M. DRUETTA, T. BOUCHAMA, S. MARTIN and J.DESESQUELLES
}

Laborato1re de Spectrometrie Ionique et Molecula1re. (CNRS UA-171), Campus de la Doua, F-69622 V1lieurbanne Cedex, France

Photon spectroscopy of low energy collisions between multicharaed lons and neutrals nas opened new possibilities of wavelength and energy level determination since recent multicharged ion sources like the EC $R$ source, giving $U A$ electric current of highly multicharged ions, are available.

The experimental set-up has been already described (1.2). The in beam is produced by an E.C.R. ion source Light emitted as a result of the collision is observed at $25^{\circ}$ to the beam axis with a $3 \mathrm{~m}$ grazing incidence (82.) spectrometer equipped with a 300 or 600 lines $/ \mathrm{mm}$ grating blazed at 55.2 or $27.6 \mathrm{~nm}$ respectively. The detection is realised by micro-channel plates (MCP).Typical beam currents are 0.45 and $0.40 \mathrm{\mu A}$ for $\mathrm{Kr}^{9+}$ and $\mathrm{Ar}{ }^{9+}$ respectively, through the $8 \mathrm{~mm}$ diameter entrance nole of the gas cell. The gas pressure was kept at $5 \times 10^{-5}$ mbar. The emission cross sections of all the new observed lines have been mesured. Taking into account the statistics; the error on the beam intensity due to double collisions; the errors on the pressure, on the relative efficiency curve of the spectrometer and on the absolute calibration; we may estimate the error bar to $\pm 30 \%$

This spectroscopic source pring together the properties of beam sources (mass and charge purity of the ions) with the propertles tled up with the physic of electron exchange.

Lines come mainly from lons having one known charge obtained by one electron capture (true with $H$ target; spectra are a little more complicated with $\mathrm{He}$ and $\mathrm{H}_{2}$ due to two electron exchange and double collisions which is minimised with low pressure target).

The electron capture is selective on a given principal quantum number $n$. which means that we know the maximum $n$ from which we mav observe transitions to lower $n$ i irst directly and secondly by cascading process. The identirication of lines is then facilitated.

In addition to these spectroscopic results. charge exchange collision study leads also to the determination of capture cross sections which are interesting in the fusion prodems. The great quantity of results obtained in these recent years gives an opportunity to test the computation codes of charge exchange processes.

we present here our preliminary results on the collisions of $\mathrm{Ar}^{9+}$ and $\mathrm{Kr}^{9}$ with $\mathrm{H}_{2}$ at $90 \mathrm{KeV}$ energy 
Typical spectra obtained at 1.07 and $225 \mathrm{kev} / \mathrm{arnu}$ for $\mathrm{Krl} x$ and $\mathrm{Al}$ ix are displayed in figure 1 and 2 respectively. All Krix lines of figure 1 are observed for the iirst time and are tentatively identified to transitions from $n=4$ levels following calculations of Wyart and Ryabtsev (3). Some

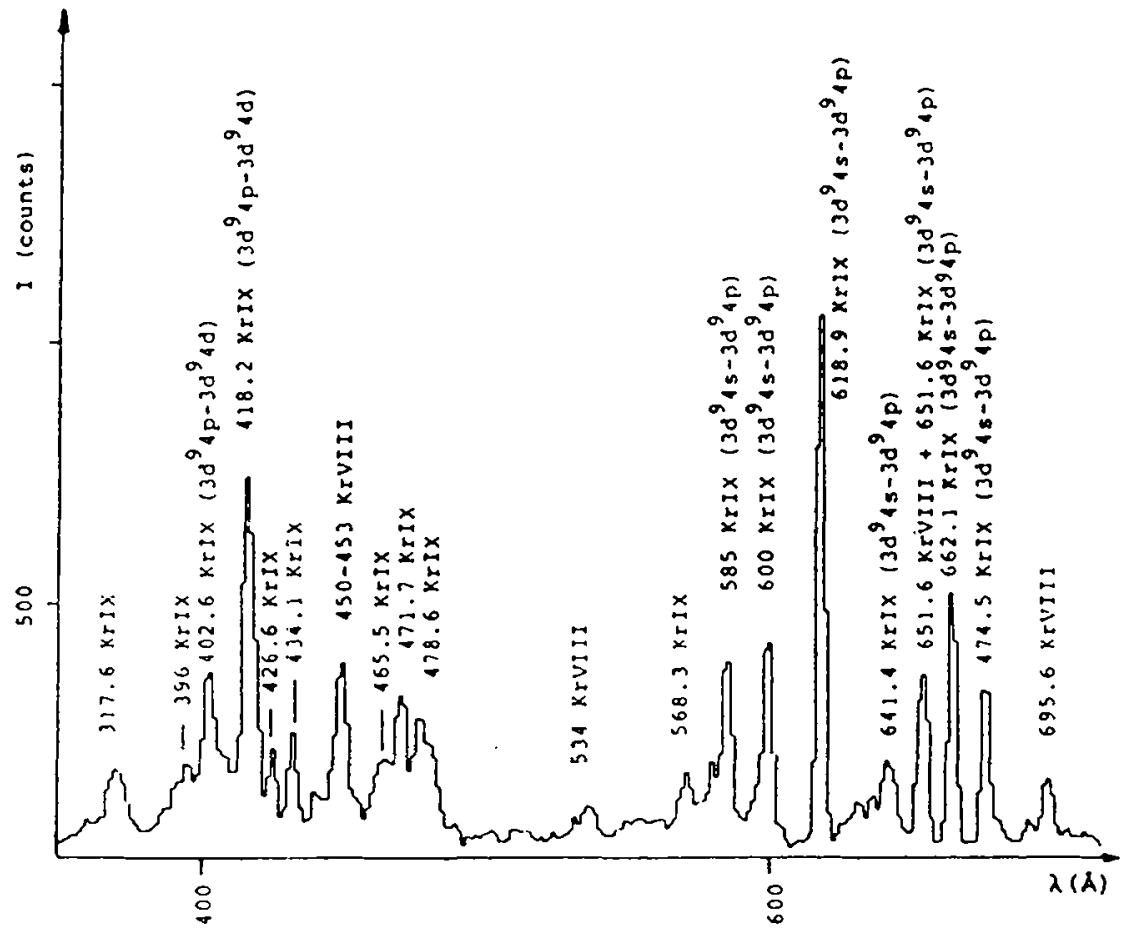

Figure 1. Partial spectrum from $\mathrm{Kr}^{9 *} \cdot \mathrm{H}_{2}$ collisions at $1.07 \mathrm{Kev} / \mathrm{amu}$

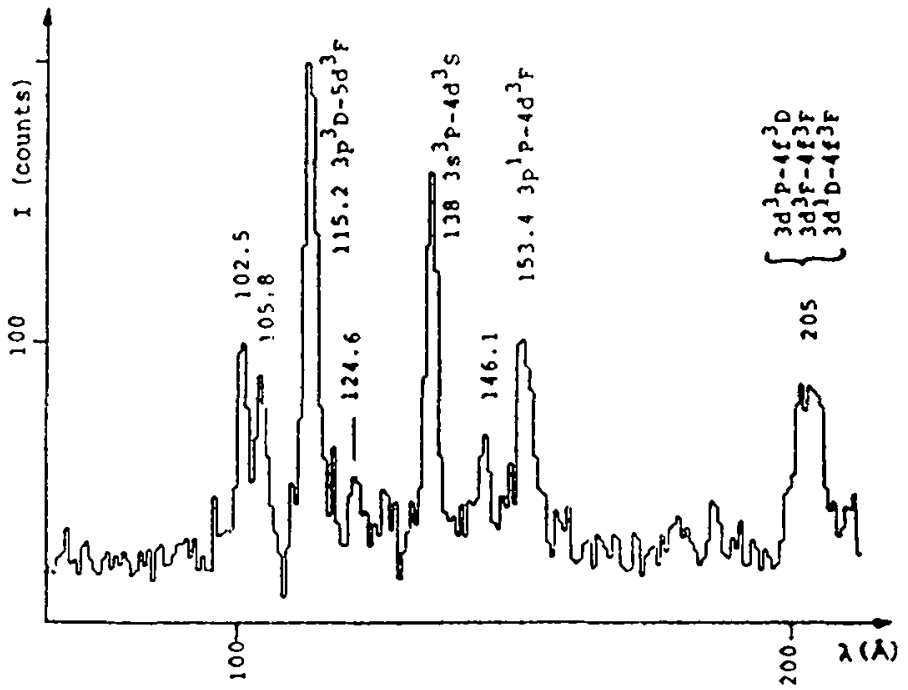

Figure 2. Partlal spectrum from $\mathrm{Ar}^{9 \cdot} \cdot \mathrm{H}_{2}$ collisions at $2.25 \mathrm{Kev} / \mathrm{am} \mathrm{u}$ 
weak k'rvill lines appear also in this spectrum. They may be due to double collisions process as we have previousiv observed for other ions in collision with $\mathrm{H}_{2}$ the spectrum of figure 2, petween $100 \mathrm{~A}$ and 200 A, shows only new lines of ArIX. Identification are based on fawcelt caiculation (4). Upper levels are $n=4$ and $n=5$.

The emission cross sections of newly observed Krix and ArIX lines are reported in tables 1 and 2

Complete results on spectroscopy and electron capture cross sections will be published later with more details and for much more observed transitions and levels. in both KriX and ArIX

This experiment was carried out at the GIS-AGRIPPA-CEA-CNRS . Grenotie.

\section{TABLE. 1}

New lines observed in $\mathrm{Kr}$ IX during the collision $\mathrm{Kr}^{9+}+\mathrm{H}_{2}$ atl.07Kev/amu. Emission cross sections $\sigma_{\mathrm{en}}\left(10^{-17} \mathrm{~cm}^{2}\right)$ within $\pm 30 \approx$ accuracy.

\begin{tabular}{|c|c|c|c|c|}
\hline $\begin{array}{c}\lambda(\lambda) \\
\text { our work }\end{array}$ & $\begin{array}{l}\text { Identification } \\
\text { (JN) }\end{array}$ & (Wyar & $\begin{array}{l}\text { and Ryabtsev) } \\
\lambda \text { théor Ique }\end{array}$ & $\sigma_{8 m}$ \\
\hline $402.6 \pm 0.5$ & \multicolumn{2}{|c|}{$3 d^{9} 4 p(3,1)-3 d^{9} 4 d(4.1)$} & 402.0 & $\ddot{0}$ \\
\hline $4182 \pm 05$ & $(\mathrm{JN})-$ & $(J N \cdot)$ & $4152-419$ & 106 \\
\hline $585.0 \pm 1$ & \multicolumn{2}{|c|}{$3 d^{9} 4 s(3,1)-3 d^{9} 4 p(3,2)$} & 583.6 & 43 \\
\hline $600.0 \pm 1$ & $(2,1)-$ & $(2,3)$ & 599.3 & 45 \\
\hline \multirow[t]{2}{*}{$618.9 \pm 0.5$} & $(3.1)-$ & $(4.1)$ & 617.8 & 86 \\
\hline & $(2,2)-$ & $(3,3)$ & 617.8 & \\
\hline $641.4 \pm 0.5$ & $(2,1)-$ & $(1,1)$ & 640.5 & 20 \\
\hline \multirow[t]{2}{*}{$602.1 \pm 0.5$} & $(1,1)-$ & $(2,2)$ & 661.1 & 48 \\
\hline & $(2.1)-$ & $(3, i)$ & 663.0 & \\
\hline $6745 \pm 05$ & $(3,1)-$ & $(2.1)$ & 6742 & 38 \\
\hline
\end{tabular}

a/fieterentice 3

\section{IABLE 11}

New lines observed in ArlX during the collision $\mathrm{Ar}^{9+}+\mathrm{H}_{2}$ at $2.25 \mathrm{Kev} / \mathrm{amu}$. Emission cross sections $\sigma_{\mathrm{em}}\left(10^{-17} \mathrm{~cm}^{2}\right)$ within $\pm 30 \&$ accuracy.

$\begin{array}{cccc}\lambda(\boldsymbol{A}) & \text { Identilication } & \begin{array}{c}\text { (Fawcett) } \\ \boldsymbol{\lambda} \text { théor ique }\end{array} & \boldsymbol{\sigma}_{\text {em }} \\ \text { our work } & & 115.2 & 29 \\ 1152 \pm 0.5 & 2 p^{5} 3 p^{3} D-2 p^{5} 5 d^{3}+ & 137.2 & 12 \\ 1380 \pm 0.5 & 3 s^{3} p-4 p^{3} S & 152.7 & 10 \\ 153.4 \pm 0.5 & 3 p^{1} p-4 d^{3} F & \end{array}$




\section{BEFERENCES}

1/ S. MARTIN. M. DRUETTA and J. DESESQuelles, Nucl. Instr. Meth. E 14 254-7 (1386)

$2 /$ M. DRUETTA, S. MARTIN and J. DESESQUELLES. Nucl. Instr.flath. 823 268-73 (1987)

$3 /$ J.F.WYART, A.N.RYABTSEV, PhYS. Scripta Vol 33. 215-22.1980

4/ B.C.FAWCETT, Phys Scripta, Vol 30, 326-3.34, 1984 